\title{
Individual Characteristic and Work Place Condition Toward Job Statisfaction of Health Worker in Aceh Indonesia
}

\author{
Teuku Salfiyadi \\ Education Management \\ Universitas Negeri Medan (UNIMED) \\ Medan, Indosenia \\ atjeh1983@live.com
}

\author{
Syaiful Sagala \\ Education Management \\ Universitas Negeri Medan (UNIMED) \\ Medan, Indosenia \\ syaiful_sagala@yahoo.co.id
}

\begin{abstract}
One of factors that determines the product quality is a person who work with full of dedication and has high profesionalism. The objective study is to find out the relation of individual characteristic and work place condition and worker statisfaction. The sample in the research are 32 workers. The method used in the study is quantitative with analytic approach. The study result shows the individual characteristic and work place condition have significant effect toward worker statisfaction $p=0,000$ smaller than 0,05 . Dependent and independent variable has strong relation $r=0,805$ or $80 \%$ and dependent variable can define independent variable, job statisfaction $r$ square $=0,647$ or $64,7 \%$, the total score of $F$ is 18,369 . It can be confirmed that $F$ count is bigger than the $F$ table, it can be seen on level of signicant $P=0,000$ ( $p<0,05)$. The individual charesteristic and work place condition has significant effect toward job statisfaction.
\end{abstract}

Keywords - Individual Characteristic; Work Place Condition; Job Statisfaction.

\section{INTRODUCTION}

In Pursuing service quality of Health worker in Aceh should consider some characeristics of job statisfaction such as age, job period, sex, and education level. Besides, considering work place condition likes compensation, promotion, work partner, supervision and job is also important, the preliminary data got from interview with various parties and observation, found the distortions as follows; some staff are undisciplined, skip work, come late; they come at 9.00 a.m and go back at 14.30 p.m, and they have never got warning from their leader. Some of them do not obey the instruction, go out on working time without inform to job partner.[1]

Marketing Management is the leading marketing text because its content and organization consistently reflect changes in marketing theory and practice. The very first edition of Marketing Management, published in 1967, introduced the concept that companies must be customer-andmarket driven. But there was little mention of what have now become fundamental topics such as segmentation, targeting, and positioning. Concepts such as brand equity, customer value analysis, database marketing, e-commerce, value networks, hybrid channels, supply chain management, and integrated marketing communications were not Marketing Management is the leading marketing text because its content and organization consistently reflect changes in marketing theory and practice. The very first edition of Marketing Management, published in 1967, introduced the concept that companies must be customer-and-market driven. But there was little mention of what have now become fundamental topics such as segmentation, targeting, and positioning. Concepts such as brand equity, customer value analysis, database marketing, e-commerce, value networks, hybrid channels, supply chain management, and integrated marketing communications were not even part of the marketing vocabulary then. Marketing Management continues to reflect the changes in the marketing discipline over the past 40 years. Firms now sell goods and services through a variety of direct and indirect channels.Mass advertising is not nearly as effective as it was, so marketers are exploring new forms of communication, such as experiential, entertainment, and viral marketing. Customers are telling companies what types of product or services they want and when, where, and how they want to buy them. They are increasingly reporting to other consumers what they think of specific companies and products - using e-mail, blogs, podcasts, and other digital media to do so.Company messages are becoming a smaller fraction of the total "conversation" about products and services.[2]

Job Satisfaction When people speak of employee attitudes, they usually mean job satisfaction, which describes a positive feeling about a job, resulting from an evaluation of its characteristics. A person with a high level of job satisfaction holds positive feelings about his or her job, while a person with a low level holds negative feelings. Because OB researchers give job satisfaction high importance, we'll review this attitude in detail later in the chapter. Job Satisfaction and Customer Satisfaction As we noted in Chapter 1 , employees in service jobs often interact with customers. Because service organization managers should be concerned with pleasing those customers, it is reasonable to ask, Is employee satisfaction related to positive customer outcomes? For 
frontline employees who have regular customer contact, the answer is "yes." Satisfied employees increase customer satisfaction and loyalty. A number of companies are acting on this evidence. The first core value of online retailer Zappos, "Deliver WOW through service," seems fairly obvious, but the way in which Zappos does it is not. Employees are encouraged to "create fun and a little weirdness" and are given unusual discretion in making customers satisfied; they are encouraged to use their imaginations, including sending flowers to disgruntled customers, and Zappos even offers a $\$ 2,000$ bribe to quit the company after training (to weed out the half-hearted). Other organizations seem to work the other end of the spectrum. Two independent reports - one on the Transportation Security Administration (TSA) and the other on airline passenger complaints - argue that low employee morale was a major factor undermining passenger satisfaction. At US Airways, employees have posted comments on blogs such as "Our planes (sic) smell filthy" and, from another, "How can I take pride in this product? [3]

Job satisfaction depends on the levels of intrinsic and extrinsic outcomes and how the jobholder views those outcomes. These outcomes have different values for different people. For some people, responsible and challenging work may have neutral or even negative value depending on their education and prior experience with work providing intrinsic outcomes. For other people, such work outcomes may have high positive values. People differ in the importance they attach to job outcomes. Those differences alone would account for different levels of job satisfaction for essentially the same job tasks. For example, one company that has initiated management systems intended to provide employees with a great deal of opportunity for exercising judgment and making decisions has found many individuals unable or unwilling to work for it. The company, W. L. Gore \& Associates, has been the subject of considerable interest among those who advocate employee empowerment. [4]

Herbert defines job statisfaction as reaction of someone to his/her job. The reaction depends on how is the job accepeted to fulfill and direct someone's need. from two quotations above the writer summarize that job statisfaction is someone respon on statisfaction feeling to do the duty.[5]

The objective study is to find out the relation of individual characteristic and work place condition characteristic toward health worker statisfaction in Aceh Indonesia.

The Joko Setiawan's research result, shows that partially (Individual) variable, individual characteristic do not influence work perfomance, while work place condition variable influence work performance. The influence of work circumstance variable is positive, the higher of work circumstance lead the higher of work performance. Thus, from the test result, only work circumstance variable proper to hyphothesis proposed. The description of each variables are as follow: 1. The influence of work circumstance toward work performance. The hyphotesis result prove there is no relation between individual characteristic and work performance. Through result count get the score $-1,538$ with level significant 0,130 , therefore $\mathrm{Ha}$ is refuesed and $\mathrm{HO}$ is accepted.
2.The influence of work circumstance toward work perfromance. The hypothesis test prove that there is relation between work circumstance toward work performance. Through count test find score 6,643 with level significant 0,000, threrefore, HO is refused ad Ha is accepted.[6]

This study provided support for the hypothesis that the relationship between job satisfaction and OCB may differ in strength based on the relative importance of cognitions vs. affect in job satisfaction measures. The BrayfieldRothe scale, suggested by Williams (1988) to be more of an affective based measure of job satisfaction, explained little variance in OCB beyond that explained by a more cognitive satisfaction measure. Specifically, when compared to the MSQ extrinsic, the Brayfield-Rothe scale explained no unique variance in four of the five citizenship behavior dimensions. This study has supported and extended the general findings of Organ and Konosvky (1989) that OCB is more likely related to cognitions about work than affect by showing the specific relationship between $\mathrm{OCB}$ and more cognitively-oriented job satisfaction However, the distinction between the BrayfieldRothe and the MSQ was not as clear as theoretically suggested. The intrinsic job satisfaction factor of the MSQ and the Brayfield-Rothe scale were both significantly correlated with a measure of positive affect and negative affect. This could indicate that the MSQ intrinsic, like the BrayfieldRothe, is more of an affectively based measure of job satisfaction. One explanation for this difference could lie in the difference in extrinsic and intrinsic items in the MSQ. For example, the extrinsic items are based on evaluating one's satisfaction with outcomes conferred upon them by someone else (pay, working conditions, policies, and praise). For these items, the respondents must look outside themselves and evaluate the relative value of "what they get." Organ and Near (1985) noted that the basis for cognitive satisfaction is for the most part "the appraisal, assessment, or evaluation of the composite external circumstances of life as made available to the individual, relative to some standard" (p. 243). The extrinsic items may be more cognitive because they appear to promote a very clear cognitive evaluation of tangible opportunities and outcomes.[7]

\section{METHOD AND RESULT}

Based on the objective study, it is descriptive quantitative study with analytic approach. The planning of study is case study on health worker in health ministry of Aceh, to find out the correlation between individual characterietic and work place toward job statisfaction of health worker in health ministry of Aceh.

From 23 Questionaires given to respondent, they have been filled completely, so the data can be processed by sofware statistic for products and sevices solution realease 13.0 .

In General distribution frequency, based on age of respondent, job period, education, attitude, compensation, promotion, job partner, suvervision, job level and job statisfaction of worker can be seen in table below: 
TABLE I

\begin{tabular}{|c|c|c|c|c|c|}
\hline \multirow{2}{*}{$\begin{array}{l}\text { Individual } \\
\text { Characteristic }\end{array}$} & \multirow{2}{*}{ Category } & \multicolumn{2}{|c|}{$\begin{array}{l}\text { Satisfaction In } \\
\text { Working }\end{array}$} & \multirow{2}{*}{ Total } & \multirow{2}{*}{$\begin{array}{l}\text { P.v } \\
\text { alu } \\
\text { e }\end{array}$} \\
\hline & & $\begin{array}{l}\text { Unsati } \\
\text { sfied }\end{array}$ & $\begin{array}{l}\text { Satis } \\
\text { fied }\end{array}$ & & \\
\hline Age & $\begin{array}{l}\text { 1. }<=30 \\
y \\
\text { 2. }>30 y\end{array}$ & 2 & 1 & 3 & $\begin{array}{l}0,2 \\
95\end{array}$ \\
\hline Length of Work & $\begin{array}{l}\text { 1. } 0-5 \text { Year } \\
\text { 2. } 6-10 \text { year } \\
\text { 3. } 11-15 \\
\text { 4. }>15 \text { year }\end{array}$ & $\begin{array}{l}4 \\
1 \\
0\end{array}$ & $\begin{array}{l}4 \\
1 \\
1\end{array}$ & $\begin{array}{l}8 \\
2 \\
1\end{array}$ & $\begin{array}{l}0,7 \\
27\end{array}$ \\
\hline Education & $\begin{array}{l}\text { 1. Senior High } \\
\text { School } \\
\text { 2. Diploma III } \\
\text { 3. BA Degree } \\
\text { 4. MA degree }\end{array}$ & $\begin{array}{l}0 \\
0 \\
7 \\
2\end{array}$ & $\begin{array}{l}1 \\
7 \\
4 \\
2\end{array}$ & $\begin{array}{l}8 \\
2 \\
11 \\
4\end{array}$ & $\begin{array}{l}0,0 \\
44\end{array}$ \\
\hline Attitude & $\begin{array}{l}\text { 1. Positive } \\
\text { 2. Negative }\end{array}$ & $\begin{array}{l}2 \\
7 \\
\end{array}$ & $\begin{array}{l}10 \\
4 \\
\end{array}$ & $\begin{array}{l}12 \\
11 \\
\end{array}$ & $\begin{array}{l}0,0 \\
21\end{array}$ \\
\hline Compensation & $\begin{array}{l}\text { 1. Satisfied } \\
\text { 2. Unsatisfied }\end{array}$ & $\begin{array}{l}1 \\
8 \\
\end{array}$ & $\begin{array}{l}12 \\
2 \\
\end{array}$ & $\begin{array}{l}13 \\
10 \\
\end{array}$ & $\begin{array}{l}0,0 \\
00\end{array}$ \\
\hline Promotion & $\begin{array}{l}\text { 1. Ever } \\
\text { 2. Never }\end{array}$ & $\begin{array}{l}0 \\
9 \\
\end{array}$ & $\begin{array}{l}9 \\
5 \\
\end{array}$ & $\begin{array}{c}9 \\
14 \\
\end{array}$ & $\begin{array}{l}0,0 \\
02\end{array}$ \\
\hline Colleague & $\begin{array}{l}\text { 1. Good } \\
\text { 2. Enough }\end{array}$ & $\begin{array}{l}3 \\
6 \\
\end{array}$ & $\begin{array}{c}12 \\
2 \\
\end{array}$ & $\begin{array}{l}15 \\
8 \\
\end{array}$ & $\begin{array}{l}0,0 \\
10\end{array}$ \\
\hline Supervision & $\begin{array}{l}\text { 1. Good } \\
\text { 2. Enough }\end{array}$ & $\begin{array}{l}2 \\
7 \\
\end{array}$ & $\begin{array}{c}11 \\
3 \\
\end{array}$ & $\begin{array}{l}13 \\
10 \\
\end{array}$ & $\begin{array}{l}0,0 \\
08\end{array}$ \\
\hline Job & $\begin{array}{l}\text { Satisfied } \\
\text { Unsatisfied }\end{array}$ & $\begin{array}{l}2 \\
7 \\
\end{array}$ & $\begin{array}{l}10 \\
4 \\
\end{array}$ & $\begin{array}{l}12 \\
11 \\
\end{array}$ & $\begin{array}{l}0,0 \\
21\end{array}$ \\
\hline & & Total & & & 23 \\
\hline
\end{tabular}

For the purpose of linearity test and regression significance, the following is the of analysis varians (ANAVA) that get from table 2

TABLE II

\begin{tabular}{|l|l|l|l|l|l|}
\hline Varians & dk & JK & RJK & $\begin{array}{l}\text { F } \\
\text { Count }\end{array}$ & F Table \\
\hline Total & 23 & 135,49 & & & \\
\cline { 1 - 3 } Regretion (a) & 1 & 129,78 & & & \\
\cline { 1 - 3 } Regresi (b|a) & 1 & 1,03 & 1,03 & \multirow{2}{*}{4,60} & \multirow{2}{*}{4,32} \\
\cline { 1 - 3 } Sisa (S) & 21 & 4,68 & 0,22 & & \\
\cline { 1 - 3 } Tuna Cocok (TC) & 12 & 2,60 & 0,22 & & \multirow{2}{*}{0,37} \\
\cline { 1 - 3 } Galat(G) & 7 & 2,08 & 0,30 & 1,37 & 3,57 \\
\hline
\end{tabular}

Analysis correlation aims to find out relation between dependent and independent variable, whether the variables have singnificant correlation. If there is significant correlation, how is the relationship direction and how is the strenght of relationship. Based on calculation of computer statistic find correlation score of motivation factors.

Individual characteristic (X1), work place (X2), toward job sttisfaction variable (Y), as follow:

TABLE III

\begin{tabular}{|c|c|c|c|c|}
\hline Variabel & & $\begin{array}{c}\text { Individual } \\
\text { Characteristi } \\
\text { c }\end{array}$ & $\begin{array}{l}\text { Work Place } \\
\text { Condition }\end{array}$ & $\begin{array}{c}\text { Statisfac } \\
\text { tion }\end{array}$ \\
\hline $\begin{array}{l}\text { Individual } \\
\text { Characteristic }\end{array}$ & $\begin{array}{l}\text { Pearson } \\
\text { Correlation } \\
\text { sig (2-tailed) } \\
\mathrm{N}\end{array}$ & 1 & $\begin{array}{c}, 491 \\
, 017 \\
23\end{array}$ & $\begin{array}{c}, 422 \\
, 045 \\
23\end{array}$ \\
\hline $\begin{array}{l}\text { Work Place } \\
\text { Condition }\end{array}$ & $\begin{array}{l}\text { Pearson } \\
\text { Correlation } \\
\text { sig (2-tailed) } \\
\mathrm{N}\end{array}$ & $\begin{array}{c}, 491 \\
, 017 \\
23\end{array}$ & 23 & $\begin{array}{c}, 804 \\
, 000 \\
23\end{array}$ \\
\hline Statisfaction & $\begin{array}{l}\text { Pearson } \\
\text { Correlation } \\
\text { sig (2-tailed) } \\
\mathrm{N}\end{array}$ & $\begin{array}{c}, 422 \\
, 045 \\
, 23\end{array}$ & $\begin{array}{c}, 804 \\
, 000 \\
23\end{array}$ & 23 \\
\hline
\end{tabular}

The influence of dependent variable, individual characteristic (X1) and work place (X2) toward independent variable, job statisfaction (Y), will be analyzed use double linear regression model with Statistics for Products and Services Solution (SPSS For Windows) program 13.0 have result as follows:

TABLE IV

\begin{tabular}{|c|c|c|c|}
\hline $\mathrm{R}=\mathbf{0 , 8 0 5}$ & & 369 & $=0,000$ \\
\hline \multicolumn{4}{|c|}{$\mathrm{Y}=0,416+0,035 \mathrm{X} 1+0,798 \mathrm{X} 2+\mathrm{e}$} \\
\hline variable & B & $\mathrm{t}$ & $\mathrm{p}$ \\
\hline Constanta & 0,416 & 1,124 & 0,274 \\
\hline Individual characteristic & 0,035 & 0,233 & 0,818 \\
\hline Work Place Condition & 0,798 & 5,161 & 0,000 \\
\hline
\end{tabular}

From the result above find age classification of health worker greater than $>40$ years, about 12 people, it is proved that statisfaction feeling on job aspect is seen from age factor, since age $>40$ years old, somebody is more interested in his job. In the study, most of respondents are male, 16 people, while females are 7 people. According to (Handoko, 1997), the older worker, they will tend to be statisfied with their job. Some main reasons are having lower expectation and well adaptation to job situation because they have more experience.[8]

Job period of Aceh health worker mostly > 15 years, 12 people. It is shown that the most average worker have done their duty, so it's impossible they have job unstatisfaction indication. It is accordance to (Muchlas, 2008), the longer, someone works in an organization, the more interested in his job.[9]

Education level of environmental health worker Aceh, mostly S-1 graduate, 11 people. It is proved that the most average has enough education level proper to their job capacity. Besides, education level also influence on job statisfaction. It is appropriate to (Siagian, 1991), said that 
education background influence on someone's job statisfaction. Worker with higher level education has well motivation because he has wide acknowledge and perception than the lower education background.[10]

Besides, environment characteristic such as; compensation, promotion, job partner, supervision and job lead positive effect toward job statisfaction because it's individual of each person has different statisfaction according with value system that applies to itself.

From the study result, it can be concluded that attitude of individual characteristic, discipline, and level of patient have significant effect toward job statisfaction, and environment characteristic; compensation, promotion, job partner, suvervision and job also have significant influence toward worker's job statisfaction.

Thanks to all who have assist so that the writer can accomplish the dissertation:

1) Director of Health Polytechnic of health ministry Aceh who permit writer to conduct research so it can give positive value for organization development in improving dan maintaining work performance of all workers.

2) Rector of Unimed who give chance to writer to study and write the index article.
3) Aisteel Unimed who conduct international seminar and give the chance to writer to present his article in front of professor

\section{REFERENCES}

[1] P. Kemenkes, "Profil Kemenkes Aceh," indonesia, 2005.

[2] P. Kotler and K. L. Keller, Marketing Management, vol. 22, no. 4. 2009.

[3] S. Robbins, Organizational Behavior. 2013.

[4] J. L. Gibson, J. M. Ivancevich, J. James H. Donnelly, and R. Konopaske, Organizations - Behavior, Structurem Processes, no. 1. 2014.

[5] J. Simonsen, "Herbert A. Simon: Administrative Behavior. How organizations can be understood in terms of decision processes," Lect. Notes, Roskilde Univ., pp. 1-12, 1994.

[6] J. Setiawan, "Pengaruh Karakteristik Individu Dan Lingkungan Kerja Terhadap Kinerja Karyawan Pada Pt.Awetama Bina Reksa," $J$. AKMENBIS Akad. Akunt. Permata Harapan, vol. II, no. 1, p. 55-70 Maret 2013 PENGARUH, 2013.

[7] R. H. Moorman, "The Influence of Cognitive and Affective Based Job Satisfaction Measures on the Relationship Between Satisfaction and Organizational Citizenship Behavior," Hum. Relations, vol. 46, no. 6, pp. 759-776, 1993.

[8] T. H. Handoko, Manajemen Personalia Dan Sumber Daya Manusia. 1997.

[9] Muchlas, "Perilaku Organisasi." 2008.

[10] Sondang P. Siagian, Teori Motivasi dan Aplikasinya. 1995. 